\begin{tabular}{|c|c|c|c|c|c|c|}
\hline \multirow{4}{*}{ Impact Factor: } & ISRA (India) & $=3.117$ & SIS (USA) & $=0.912$ & ICV (Poland) & $=6.630$ \\
\hline & ISI (Dubai, UAE & $=0.829$ & РИНЦ (Russia) & $=0.156$ & PIF (India) & $=1.940$ \\
\hline & GIF (Australia) & $=0.564$ & ESJI (KZ) & $=8.716$ & IBI (India) & $=4.260$ \\
\hline & JIF & $=1.500$ & SJIF (Morocco) & $=5.667$ & OAJI (USA) & $=0.350$ \\
\hline
\end{tabular}

\section{SOI: $1.1 /$ TAS $\quad$ DOI: $10.15863 /$ TAS International Scientific Journal Theoretical \& Applied Science}

p-ISSN: 2308-4944 (print) e-ISSN: 2409-0085 (online)

Year: 2019 Issue: $05 \quad$ Volume: 73

Published: $15.05 .2019 \quad \underline{\text { http://T-Science.org }}$
QR - Issue

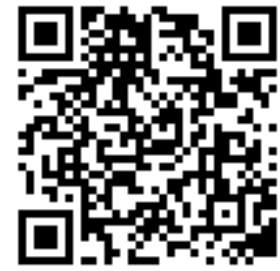

UDC:81'373.421

\title{
PROBLEMS OF CREATING NATIONAL CORPUS OF THE UZBEK LANGUAGE (level of synonyms)
}

\begin{abstract}
The paper presents opinions concerning synonyms, history of their research, synonymic paradigm and questions related to synonyms on creating the national corpus of the Uzbek language.

Key words: synonyms, research of synonyms in antique period, the problems of creating national corpus of the Uzbek language.

Language: English

Citation: Eshmuminov, A. (2019). Problems of creating national corpus of the Uzbek language. Level of synonyms. ISJ Theoretical \& Applied Science, 05 (73), 47-50.
\end{abstract}

Soi: http://s-o-i.org/1.1/TAS-05-73-10 Doi: crossef https://dx.doi.org/10.15863/TAS.2019.05.73.10

\section{INTRODUCTION}

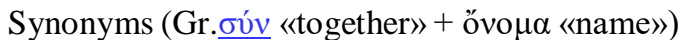
are the words belonging one parts of speech and language, but different in writing and pronunciation, but similar meaning. It should be noted that, the synonymic phenomenon has become one of the urgent problems not only of linguistics, but also of ancient philosophy. Particularly, in Platon's work "Kratil", this is the subject of debate with Socrates.

The philosophers stressed out to the oratory speech in the philosophy period of ancient Greek linguistics. Hence, the works on stylistics and synonyms that directly serve to the oratory speech could be found in Greek Linguistics in the VIth and Vth centuries BC. For example, Prodyk, who developed the theory of synonyms in the fifth century $\mathrm{BC}$, noted that the knowledge on homonyms and synonyms were important for orators and poets [1]. Another philosopher, Democritus, concluded that there is no connection between the thing and its name, and as a proof of that, he makes examplesof the homonymous and synonymous words (1).

In general, the study of synonyms and the creation of dictionaries related with synonyms have a long history, and the value of these lexicographical works is high in creation of national corpus of the world languages. Similarly, when creating the national corpus of the Uzbek language, the essence of this issue is seen in the dictionaries created up today.

\section{MAIN PART}

Thoughmany studies have been conducted in the Uzbek linguistics for the study of synonyms, the wellknown linguist A.Hojiev said: "The synonyms have been studied differently in different languages. Although this issue has been deeply studied in some languages, some languages, including in Uzbek linguistics it is not studied well. Expressed inguistic views, often do not correspond to each other. This phenomenon, first of all, is evident in the definition of synonyms» [2]. However, the study of synonyms in Uzbek linguistics has its own historical evolution, which can be conditionally divided into the following stages:

-I stage: 1950-1960;

-II stage: 1960-1980;

- III stage: 1980-2000;

- IV stage: 2000 and next years.

All references, including «Uzbek Lexicon» by Fahri Kamal, D. Pinkhasov's «The Modern Uzbek Language Lexicon», which were published under the heading of «Hozirgi zamon o`zbek tili kursidan materiallar» («Materials from the Present Day Uzbek Language Course») played a significant role in the formation of Uzbek lexicon[3]. On the eve of the 70th years of the XXth century, the linguist Ya.P.Pinkhasov paid a serious attention to the semantic nature of synonyms in the Uzbek language and divided them into two parts in terms of meaning: 1. Idiographical synonyms are synonyms that are used interchangeably in every time, in every text: буюк/улув, дунё/юахқон/олам, куัк/осмон, 


\begin{tabular}{|c|c|c|c|c|c|c|}
\hline \multirow{4}{*}{ Impact Factor: } & ISRA (India) & $=3.117$ & SIS (USA) & $=0.912$ & ICV (Poland) & $=6.630$ \\
\hline & ISI (Dubai, UAE & $=0.829$ & РИНЦ (Russia) & $=0.156$ & PIF (India) & $=1.940$ \\
\hline & GIF (Australia) & $=0.564$ & ESJI (KZ) & $=8.716$ & IBI (India) & $=4.260$ \\
\hline & JIF & $=1.500$ & SJIF (Morocco) & $=5.667$ & OAJI (USA) & $=0.350$ \\
\hline
\end{tabular}

сўзламоқ/гапирмоқеtс. 2. Stylistic synonyms are synonyms that are not equally used in any text and are distinguished by their sensitivity:буюк/улув, улкан/катта/зуррагант (буюк бинолар, улуг бинолар, улкан бинолар, катта бинолар, зўр бинолар, гигант бинолар).

In addition, the scientist divided synonyms into three categories according to their structure: 1 . Individual synonyms: керак/лозим; тез/(чаққон/илдам; азиз/мехрибон еtс. 2. Pair synonyms: сов-саломат, эл-юрт, бахтcаодаm, қ̧ахр-вазаб еtc. 3. Compound synonyms (synonymous phrases): юзи қора/ бети қора, ори йуқ/номуси йў; эрта билан/ қуш уйвонмай; кеч киргунча/қуош қорайгунчаетс.

Ya.P.Pinkhasov points out that synonyms are related to the word families and synonyms formed with the help of nouns, adjectives, pronouns, adverbs, functional words, conjunctions and modal words. Besides, the scientist also says that the synonyms / lexical synonyms in the language originate in three ways. These are: 1. Some words pass from local dialects equivalent to one word (a common word for all dialect) existing in common peoples` language; 2. A word passes from one language to another; 3 . Synonyms that arise as a result of the closeness and similiarities of words [4].

Similarly, the well-known linguist R. Kungurov explained the phenomena of synonyms in his monograph «Ўзбек тилининг тасвирий воситалари» (Expressive means of the Uzbek language)», published in 1977. The scientist notes different semantic types of the verb "қарамоқ" (to look) in the Uzbek language: аланг-жаланг, жовдир-довдир қарамоқ,, ола-кула, довдиржовдир, муглт-мўлт, вилт-вилт; жовдираб, аланглаб, бақрайиб, анграйиб, хуймрайиб, ишиайиб, тикрайиб, адрайиб қарамоқ. Therefore, an expert in Uzbek stylistics would write that: The modern Uzbek language have such several synonymous expressive words as ,yв тортиб йивламоқ, уввос тортиб йивламоқ, ув-в.., пикпик..., хуйнг-хўнг.., хуўнгир-хуунгир.., уукраб, ингаинга.., бав-бав, пих-пих, чир-чирйивламоқ'[5], he repeatedly proves scientifically the unlimited opportunities of the Uzbek language.

In the 80 's of the XXth century, on the basis of the rigorous study of the methodology of the Uzbek language, many linguists had proposed their own definitions about synonyms. In particular, E.Kilichev notes differentiation of synonymous rows according to the following relations: 1 . In terms of emotionalexpressive coloring; 2 . The style, which they belong to; 3. Regarding the relation between the literary language and the dialect. He also distinguishes the wide range synonyms and types of poetic synonyms [6]. (By the 90s of the XX century, the scientist described his views on grammatical synonymy in his Handbook "Ўзбек тилининг амалий стилистикаси"
(Practical Stylisticsof the Uzbek language [7].In its turn, it should be noted that such description was written in A.Hojiev's previously published dictionary «Ўзбек тили синонимларининг изохли луғати» (Explanatory dictionary of Uzbek synonyms)[2].

As abovenoted, the analysis of synonymy with semantic sensitivity was accelerated in the 90's and subsequent years. In particular, the well-known representative of Uzbek lexicology B.Yuldashev [8]having analyzed the synonyms noted that,synonyms differ not only with their semantic sensitivity, but also its stylistic coloring, and the field of application. Besides, the linguist H.Shamsiddinov also notes that synonyms together with having the same meaning which unite them, and have a distinctive character, and for the one who considers the synonymy as a same lexical meaning expresses the following idea: «synonymy do not appear on the basis of lexical meaning and the meaning of the word realized in the context»[9].

Similarly, Odiljon Bazarov's study dedicated to thegradonymy in the Uzbek language is also a serious study on this problem. In this case, the scientist has revealed the Uzbek language gradonymy regulations through natural-ontological, philosophical, logical, and gnoseologicalmethodological essense [10].

It is evident, that in the second half of the 20th century, the attitude to the synonymy of words (syntactic constructions) developed in Uzbek linguistics, and studies in this area have not been diminished in the XXIst century Uzbek linguistics. However, the textbook «Хозирги ўзбек адабий тили» (Modern Uzbek literary language) written by R.Sayfullayeva, B.Mengliev, G.H. Boqieva, M.Kurbonova, Z.Q.Yunusova, M.K.Abuzalova, and its chapter named "Lexic-Semantic Relationships" and the part named "Lexic-semantic selationships" of the «Modern Uzbek language» written by professor B.Mengliev give valuable ideas about synonymous relations. Professor M.Mirtojiev in his monograph «Semiology», professor S.Karimov in his monograph «Artistic style of the Uzbek language» give remarkable views about synonyms.

A researcher G.Rahmonov, who studied the relationship between linguistic synonymy and gradonymy of the Uzbek language, mentions the researches of Uzbek linguists who worked on the problem: Sh. Rahmatullaev, R.Yunusov, E. Kilichev, E.Begmatov, H.Nematov, A.Nurmonov, R.Rasulov, S.Giyasov, R.Safarova, O.Bozorov, D.Khodjaeva, Sh.Orifjonova, H.Shamsiddinov, L.Khudoyberdieva, N. Shirinova, J.Djumabayeva .

It is necessary to note, serious attention was paid to the development of linguistic thoughtsof the Uzbek linguistics societymembersduring the first decade of the $21 \mathrm{st}$ century. Particularly, the publication of the "Academic Dictionary of the Uzbek Language words gradonymy" [11] to increase the 


\begin{tabular}{|c|c|c|c|c|c|c|}
\hline \multirow{4}{*}{ Impact Factor: } & ISRA (India) & $=3.117$ & SIS (USA) & $=0.912$ & ICV (Poland) & $=6.630$ \\
\hline & ISI (Dubai, UAI & $=0.829$ & РИНЦ (Russia & $=0.156$ & PIF (India) & $=1.940$ \\
\hline & GIF (Australia) & $=0.564$ & ESJI (KZ) & $=8.716$ & IBI (India) & $=4.260$ \\
\hline & JIF & $=1.500$ & SJIF (Morocco & $=5.667$ & OAJI (USA) & $=0.350$ \\
\hline
\end{tabular}

creative thinking of schoolchildren is a serious achievement in this regard. Similarly, putting forward the problem of synonyms ' attitude towards paradigm ${ }^{1}$ in professor B.Mengliev's textbook «The Modern Uzbek Literary Language»[12] is a novelty for present day Uzbek linguistics.

But frankly speaking, dictionaries of synonyms in the Uzbek language can not serve fully to lexicalsemantic marking of synonyms in the future. Because, the creation of lexicographical works on synonyms is not well developed in the Uzbek language. However, Russian and European linguistics is quite advanced in this regard. For the sake of comparing and thinking, we get the «Thesaurus Dictionary of Russian language synonyms».

The dictionary-thesaurus of the Russian language synonyms (ideographical dictionary) is a relatively new phenomenon in lexicography. It shows how many synonymic rows belong to several ideographical groups. The dictionary describes 7528 synonymic rows consisting of 40,000 words representing a total of 39,246 expressions. These synonymic rows are subdivided into 16 semantic fields, 430 ideographic groups and subgroups according to the gradual (hierarchical) expression of notions. In addition, the alphabetical indicator of words, which are being searched, helps to find not only synonyms of the given word, but also will help quickly and easily find the synonymic rows of the given word, which are compared according to their common ideographic characters with the synonymic rows ${ }^{2}$.

Naturally, this dictionary is based on the principles of structured linguistics and such kind of dictionaries have not been compiled in the Uzbek language (if we don't take into consideration "The academic dictionary of same meaning words of the Uzbek Language" [13] and the "Academic Dictionary of words` gradation of the Uzbek Language). Existing ones are purely educational, and can not express their analytical attitude to the scientific problem themselves. However, synonymous words are a clear (concrete) system of linguistic units that are bound by a concrete semantic connection. The lexical paradigms associated with this particular semantic linkage, in its turn, constitute a unite microsystem. This is evidenced by the fact that it is interconnected with the existing meanings of each element within the framework of microsystem [14].

Also, differentiating integral and differentiated characters of synonyms in the dictionary will help to analyze synonyms and to define their synonymic rows. In this case, the issue of determining the core and semantic boundary in the synonymic rows is actualized even more.

The synonymic nucleus is composed of several semes and is equally important for row members. However, the key word (dominanta) and the closely related words are also significant in increasing the sensitivity of the speech. In particular, the meaning of the lexical dominant is completely or partially correspond to the general meaning of the synonymic rows. Therefore, the dominant determines the boundary of the synonymic rows, and approximate boundary of the development scale that entire paradigm can follow [15].

\section{CONCLUSION}

It appears that, the dictionaries of synonyms in the Uzbek language do not help much in setting up synonyms into lexical-semantic (according to lexicalsemantic groups) marking. This will not affect the accuracy of the marking up process. Nevertheless, commentaries and interpretations given to synonyms can be used as a source.

\footnotetext{
${ }^{1}$ The issue of adhering to the paradigm of synthesis in fan science has been put forward by A. Nurmanov on the example of Alisher Navoi's (in synonyms) word-by-speech. At the end of the sixties, the question of separation of the lexical-semantic groups known in the Western European and later Russian linguistics system into lexical-semantic groups with synonymic and antonymic paradigms is also remarkable. However, the separation and theoretical study of the hyponymic rows in the Uzbek-language dictionary sets the definition of hyponomic and synonymy relationships, and hyponimia and antonymia. (See: Сафарова P. Лексик-семантик муносабатнинг турлари. - Тошкент: Ўқитувчи, 1996. -Б. 3; 24.).
}

However, in the case of B. Mengliev in this regard, it is possible to analyze the problem, critically examine the critical approach to the problem.

${ }^{2}$ It should be noted that today, buildings with a semantic precision are extremely small. Accordingly, the creation of perfect dictionaries of synonyms accelerates research on this subject.See: Бабенко Л. Г.Editor: Бабенко Людмила Григорьевна. M.:: АCT-Преcc, 2017. https://www.labirint.ru/books/157094/?utm_content=topadvert_2 block-name_v-teaser_clickid_2_pin_2887584653902290005 


\begin{tabular}{llllll} 
& ISRA (India) $=\mathbf{3 . 1 1 7}$ & SIS (USA) $=\mathbf{0 . 9 1 2}$ & ICV (Poland) & $\mathbf{= 6 . 6 3 0}$ \\
Impact Factor: & ISI (Dubai, UAE) $=\mathbf{0 . 8 2 9}$ & PUHЦ (Russia) $=\mathbf{0 . 1 5 6}$ & PIF (India) & $=\mathbf{1 . 9 4 0}$ \\
& GIF (Australia) $=\mathbf{0 . 5 6 4}$ & ESJI (KZ) & $\mathbf{8 . 7 1 6}$ & IBI (India) & $=\mathbf{4 . 2 6 0}$ \\
& JIF & $\mathbf{1 . 5 0 0}$ & SJIF (Morocco) $=\mathbf{5 . 6 6 7}$ & OAJI (USA) & $\mathbf{0 . 3 5 0}$ \\
\hline
\end{tabular}

\section{References:}

1. Usmonov, S. (1972). Umumiy tilshunoslik. (p.22, p.18). Toshkent: Uқituvchi.

2. Xozhiev, A. (1974). Uzbek tili sinonimlarining izox̧li luzati. (p.308). Toshkent: Ukituvchi.

3. Nurmonov, A. (2002). Uzbek tilshunosligi tarikhi. (p.183). Toshkent: Uzbekiston.

4. Pinkhasov, Y. D. (1969). Xozirgi yzbek adabiy tili. Leksikologiya va frazeologiya (Pedagogika institutlari filologiya fakul'tetlarining sirtқ̧i by̆lim studentlari uchun ky̆llanma). (pp.25-27). Toshkent: Ukituvchi.

5. Kungurov, R. (1966). Uzbek tilida tasviriy suzlar. (pp.44-45). Toshkent: Fan.

6. Kilichev, E. (1985). Uzbek tilining praktik stilistikasi. (p.32). Toshkent: Ukituvchi.

7. Kilichev, E. (1992). Uzbek tilining amaliy stilistikasi. Toshkent: Ukituvchi.

8. Yuldashev, B. (1998). Frazeologik uslubiyatasoslari. Ukuv kullanmasi. (p.200). Samarқand: SamDUnashri.

9. Shamsiddinov, X. (2008). Suzlar funktsionalsemantik sinonimlarining shakliy va ma"noviy tabiati. Ukuv ky̆llanma. (p.4). Toshkent: Universitet.

10. Bazarov, O. (1997). Uzbek tilida darazhalanish. Filologiya fanlari doktori ilmiy darazhasini olish uchun taķdim etilgan dissertatsiya avtoreferati. Toshkent.

11. Bobojonov, S., Islomov I. (2007). O`zbek tilining so`zlar darajalanishi o`quv lug`ati. Toshkent: Yangi asr avlodi.

12. Mengliyev, B. (2018). Hozirgi o'zbek tili. (kirish, fonetik sath, leksik-semantik sath). Toshkent: Tafakkur bo'stoni.

13. Shukurov, O., \& Bahriddinova, B. (2006). O'zbek tilining ma'nodosh so'zlar o'quv lug'ati. Maktab o'quvchilari uchun. Toshkent.

14. Safarova, R. (1996). Leksik-semantik munosabatning turlari. (p.3, p.24). Toshkent: Ukituvchi.

15. (n.d.). Retrieved 2019, from https://studme.org/113414/literatura/obschaya_ harakteristika_sinonimov_sinonimicheskogo_ry ada 